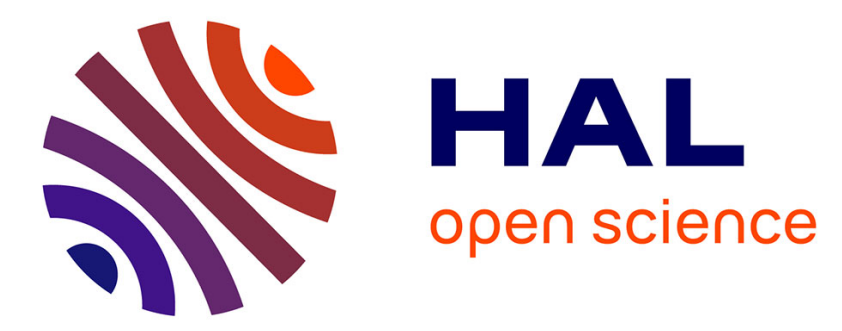

\title{
Volcanological Map of the Plaine des Sables, Piton de la Fournaise
}

\author{
Claudia Principe, Andrea Morandi, Andrea Di Muro, Laurent Michon
}

\section{To cite this version:}

Claudia Principe, Andrea Morandi, Andrea Di Muro, Laurent Michon. Volcanological Map of the Plaine des Sables, Piton de la Fournaise. Patrick Bachelery, Jean-François Lenat, Andrea Di Muro, Laurent Michon Active volcanoes of the western Indian Ocean: Piton de la Fournaise and Karthala, Springer, pp.327-330, 2016, Active volcanoes of the World, 978-3-642-31394-3. 10.1007/978-3-64231395-0_20.hal-01384595

\section{HAL Id: hal-01384595 \\ https://hal.univ-reunion.fr/hal-01384595}

Submitted on 27 Oct 2016

HAL is a multi-disciplinary open access archive for the deposit and dissemination of scientific research documents, whether they are published or not. The documents may come from teaching and research institutions in France or abroad, or from public or private research centers.
L'archive ouverte pluridisciplinaire HAL, est destinée au dépôt et à la diffusion de documents scientifiques de niveau recherche, publiés ou non, émanant des établissements d'enseignement et de recherche français ou étrangers, des laboratoires publics ou privés. 


\title{
Volcanological Map of the Plaine des Sables, Piton de la Fournaise
}

\author{
Claudia Principe, Andrea Morandi, Andrea Di Muro \\ and Laurent Michon
}

The "Plaine des Sables" (PdS) is the main entry door for the visitor approaching the summit area of Piton de la Fournaise (PdF) basaltic shield volcano. The plain, located between 2300 and $2400 \mathrm{~m}$ asl and $5 \mathrm{~km}$ west of PdF summit crater, owes its name to a m-thick continuous cover of basaltic lapilli that strongly contrast with the dominantly effusive behavior of PdF. Several cones of variable volume and size and related lava flows occur scattered inside the PdS.

This map is the first detailed map of PdS and represents a first attempt to introduce synthematic units for the study of the Piton de la Fournaise volcanological district. The new cartography is

C. Principe $(\bowtie) \cdot$ A. Di Muro

Istituto di Geoscienze e Georisorse, CNR Pisa, Italy e-mail: c.principe@igg.enr.it

A. Morandi

Dipartimento di Scienze della Terra, University of Florence, Florence, Italy

A. Di Muro

Observatoire Volcanologique du Piton de la Fournaise (OVPF), IPGP, Bourg Murat, France

L. Michon

Laboratoire GéoSciences, Université de La Réunion and IPGP, Saint Denis, France offered in this first version with a relatively detailed resolution (1:5000) and on a DEM base (courtesy of N. Villeneuve, OVPF). Synthematic mapping is based on unconformity surfaces, which permit to define key geological events inside the stratigraphic succession of volcanic deposits (Salvador 1987). In the PdS case, this approach allowed grouping the whole PdS activity occurred after the collapse of the "Plaine des Sable" caldera (Plaine des Sables Synthem; $<60$ 24 ka; Merle et al. 2010; Staudacher and Allègre 1993) by means of a first order unconformity represented by the collapse scarp itself. The eastern side of the PdS is bounded by a second scarp related to the younger $(<4.8 \mathrm{ka})$ "Enclos Fouqué" caldera (Bachèlery 1981; Ort et al. 2015). Inside the PdS Synthem, the stratigraphic unit of Bellecombe ashes (\#bac) groups at least three eruptive events occurred between $4880 \pm 35 \mathrm{BP}$ and $2855 \pm 35$ BP (Morandi et al. 2016; Ort et al. 2015) and represents the main depositional marker over the whole PdS area. Bellecombe ashes were emplaced during the main explosive (phreatomagmatic) event known at PdF (Bachèlery 1981; Michon et al. 2013; Morandi et al. 2016) and whose source area was partly located inside the PdS itself (Ort et al. 2015). Several cones (e.g. \#c) and voluminous lava units (\#ol and \#oc) predate Bellecombe activity. The age of \#oc lavas emitted before Enclos Fouqué collapse by central vents located east of the PdS is in the range 5.1-3.5 ka (Staudacher and Allègre 1993). Lavas range from 

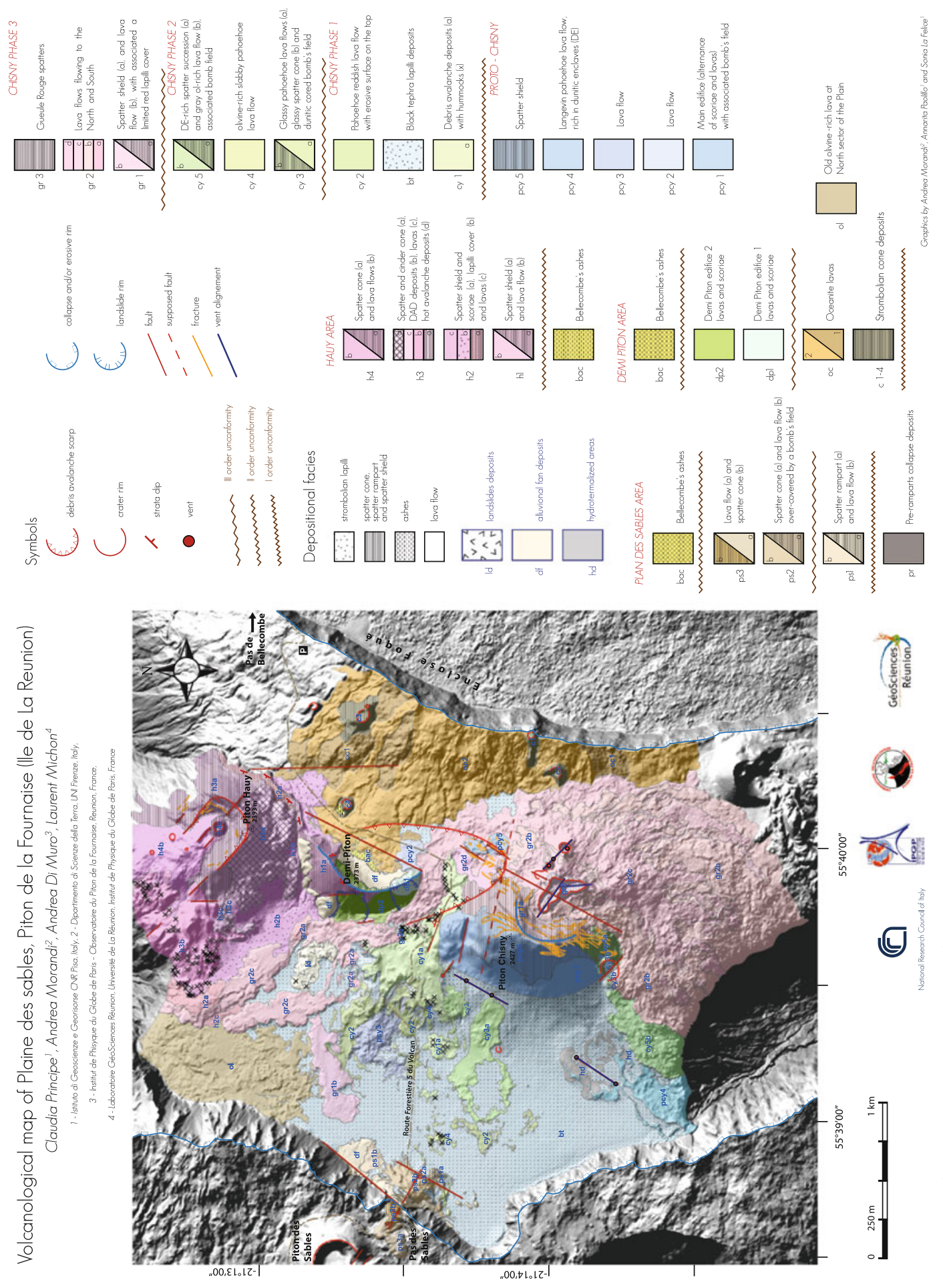

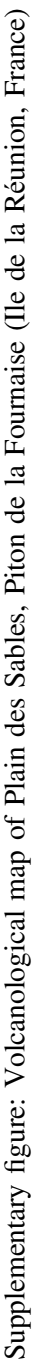

$\bar{n}$

운 
aphyric to olivine-rich (oceanite) basalts and span the whole range of surface textures known at PdF (Morandi et al. 2015). An outstanding feature of many lavas cropping out in the PdS is the abundance of ultramaphic (dunite-werhlite) nodules, testifying unusually deep magmatic storage levels (Bureau et al. 1998).

Two main lapilli units (Chisny Black Tephra, \#bt and Haüy Yellow Tephra \#h2) permit stratigraphic correlation across most of the PdS area. Beside typical monogenetic activity widespread on PdF massif, at least three large polygenetic centers can be identified inside PdS: Demi Piton, Piton Chisny, and Piton Haüy (Michon et al. 2015; Morandi et al. 2015, 2016). Their eruptive dynamics ranges from violent lava fountaining (e.g. \#bt and \#h2) to long lasting effusive behavior (e.g. 'Gueule Rouge' lava lake, east of Chisny Rampart; \#gr3). With the notable exception of Bellecombe ashes, phreatomagmatic activity seems to play only a very minor role in the activity of the PdS. Bellecombe ashes have been grouped in a single sub-synthem, which permits to propose a relative chronology for the largest cones of the PdS, namely Demi Piton \#dp (pre-Bellecombe), Haüy \#h and Chisny cones \#cy and \#pcy (post-Bellecombe). The main age constraints for the youngest part of the volcanic sequence correspond to a radiocarbon age of $1105 \pm 60 \mathrm{BP}$ for a lava down the Langevin valley (Bachelery 1981; Tanguy et al. 2011) and an even younger age for the Black Tephra fall emplaced during the late activity of Chisny cone (381 \pm 26 BP; Morandi et al. 2016). Mapping of Piton Chisny and Piton Haüy products highlights the presence of two Debris Avalanches deposits (DAD \#cy1 and \#h3b) and related scarps and hummocks, as well as the morphological evidence of a number of eruptive and non-eruptive fractures.

The unvegetated lapilli cover which gives the name to the Plaine des Sables was mainly originated from the young activity of lava fountaining of Chisny (southern part of the plain) and Haüy (northern part of the plain) eruptive centers. In the central and northern portion of the map, other minor lapilli blankets are present, but have very limited dispersion, confined close to the source areas (Morandi et al. 2016).

Our work demonstrates that the Plaine des Sables has been the site of frequent and sometimes violent eruptive activity even in recent times, shortly before the beginning of human settlement on the La Réunion island. This excentric activity of PdF was periodically able to shed ashes and lapillis all over and outside the Plain des Sables. The most voluminous eruptions emitted lavas able to propagate down the main valleys, towards the villages and the towns located at the feet of the PdF massif. Most important, this excentric activity does not correspond only to monotonous piling of lavas or mild strombolian activity from a single constant source. PdS activity indeed developed on scattered and sometimes long-living eruptive centers and was able to produce a wide span of eruptive behaviors and volcanic hazards. The Plaine des Sables must therefore be considered as one of the most active and potentially hazardous sectors of the PdF massif (Di Muro 2012 and 2015).

\section{References}

Bachèlery P (1981) Le Piton de la Fournaise (Ile de la Reunion). Etude volcanologique, structurale et petrologique du Piton de la Fournaise, Ile de La Reunion Volcanological, structural and petrological study of Piton de la Fournaise, La Réunion island. PhD thesis, University of Clermont-Ferrand, Clermont-Ferrand, pp 255

Bureau H, Métrich N, Pineau F, Semet PM (1998) Magma-conduit interaction at Piton de la Fournaise volcano (Réunion island): a melt and fluid inclusion study. J Volcanol Geoth Res 84:39-60

Di Muro M (2012 and 2015) Evaluation de l'aléa volcanique a La Réunion. Rapport final-année I et année II. Projet BRGM/IPGP

Merle $\mathrm{O}$, Mairine $\mathrm{Ph}$, Michon L, Bachèlery P, Smietana M (2010) Calderas, landslides and paleo-canyons on Piton de la Fournaise volcano (La Réunion island, Indian Ocean). J Volcanol Geoth Res 189:131-142

Michon L, Di Muro A, Villeneuve N, Saint-Marc C, Fadda P, Manta F (2013) Explosive activity of the summit cone of Piton de la Fournaise volcano (La Réunion island): a historical and geological review. J Volcanol Geotherm Res 263:117-133 
Michon L, Ferrazini V, Di Muro A, Villeneuve N, Famin V (2015) Rift zones and magma plumbing system of Piton de la Fournaise: how do they differ from Hawaii and Etna? J Volcanol Geotherm Res 303:112-129

Morandi A, Principe C, Di Muro A, Bachelery P (2015) Polygenetic hawaiian activity at Piton de la Fournaise volcano (Plaine des Sables; La Réunion Island). J Volcanol Geoth Res (submitted)

Morandi A, Di Muro A, Principe C, Michon L, Leroi G, Norelli F, Bachèlery P (2016) Pre-historic explosive activity at Piton de la Fournaise volcano. In: Bachèlery P, Lénat JF, Di Muro A, Michon L (eds) Active volcanoes of the Southwest Indian Ocean: Piton de la Fournaise and Karthala. Active Volcanoes of the World. Springer, Berlin
Ort M, Di Muro A, Michon L, Bachèlery P (2015) Explosive eruptions from the interaction of magmatic and hydrothermal systems during flank extension: the Bellecombe ashes of Piton de la Fournaise (La Réunion Island). Bull Volcanol (accepted)

Salvador A (1987) Unconformity-bounded stratigraphic units. Geol Soc Am Bull 98:232-237

Staudacher T, Allègre CJ (1993) Ages of the second caldera of Piton de la Fournaise volcano (Réunion) determined by cosmic ray produced ${ }^{3} \mathrm{He}$ and ${ }^{21} \mathrm{Ne}$. Earth Planet Sci Lett. 119:395-404

Tanguy JC, Bachèlery P, Le Goff M (2011) Archeomagnetism of Piton de la Fournaise: bearing on volcanic activity at La Réunion Island and geomagnetic secular variation in Southern Indian Ocean. Earth Planet Sci Lett 303:361-368. doi:10.1016/j.epsl.2011.01.019 